\title{
Reanalysis of the patients who were diagnosed with hystero-epilepsy by Charcot
}

Tomoko Komagamine ( $\nabla$ tkoma@dokkyomed.ac.jp )

Dokkyo Medical University https://orcid.org/0000-0001-8005-8509

Norito Kokubun

Dokkyo Medical University

Koichi Hirata

Dokkyo Medical University

\section{Research article}

Keywords: hystero-epilepsy, Charcot, anti-NMDA receptor encephalitis, dissociative disorder, drug withdrawal, schizophrenia, ketamine

Posted Date: January 14th, 2020

DOI: https://doi.org/10.21203/rs.2.20665/v1

License: (9) (i) This work is licensed under a Creative Commons Attribution 4.0 International License. Read Full License 


\section{Abstract}

Background: The term "hysteria" is now recognized to refer to non-organic and functional disorders. Jean-Martin Charcot once attempted to identify the lesions responsible for hysteria as an organic disorder in his later years, but his effort failed. He classified hysteria as usual and grand. Grand hysteria was also called hystero-epilepsy, which became obsolete after Charcot's death and has been an enigma in modern neurology. After anti-NMDA receptor (NMDAR) encephalitis was established in the twenty-first century, a paradigm shift emerged in the interpretation of acute onset of neuropsychiatric symptoms. Patients with anti-NMDAR encephalitis demonstrate a characteristic multistage progression and stereotypical movements, including opisthotonic posture, which are analogous to the staging progressions and ' arc de cercle' observed in Charcot's hystero-epilepsy.

Methods: To elucidate the full picture of Charcot's hystero-epilepsy, we reviewed the patients presented in "the Tuesday Lessons".

Results: Eleven patients were shown to have hystero-epilepsy by Charcot himself. Of the 11 patients, 4 patients had acute-onset neuropsychiatric symptoms, and 2 patients had a condition that resembled anti-NMDAR encephalitis. Although the clinical courses were similar to those of anti-NMDAR encephalitis, we could not make conclusive diagnoses of anti-NMDAR encephalitis without examinations due to the lack of evidence of teratomas. One patient with alcohol withdrawal syndrome and one patient with chronic pain and morphine withdrawal syndrome were also classified as having hystero-epilepsy by Charcot. The other patients, who manifested chronic courses or varying hypnosis-induced neurological symptoms, could be diagnosed with conversion and dissociative disorders today.

Conclusions: Charcot's hystero-epilepsy has been suspected of being a syndrome encompassing conversion and dissociative disorders, drug withdrawal syndrome, and anti-NMDAR encephalitis-like manifestations. Charcot's observations combined with the current progress in molecular biology suggest that a common dysfunctional basis exists, such as glutamate/NMDAR system dysfunction, among these conditions.

\section{Background}

The term hysteria has been recognized as a synonym for functional neurological disorders including conversion and dissociative disorders. However, in the nineteenth century, there was no clear discrimination between functional and organic disorders. Jean-Martin Charcot, a preeminent neuroanatomist, anticipated focal brain lesions of hysteria, but his efforts have not yet been archived [1]. The consensus of hysteria as a nonanatomical disorder was widely accepted soon after Charcot's death in the early twentieth century [2,3]. Charcot classified hysteria into two subtypes: usual hysteria and grand hysteria [4]. The usual hysteria included various manifestations, such as tunnel vision, hemiaesthesia, rhythmic chorea, mutism and paralysis [5], or was inducible by hypnosis [1]. This type of hysteria corresponds to conversion and dissociative disorders, which have been investigated and have shown distinctive brain activation patterns associated with functional deficits in recent functional imaging studies [6]. The latter type, grand hysteria, was also called hystero-epilepsy, which characterized a combination of various psychiatric and bizarre neurologic manifestations and became an enigma of modern neurology because it was not recognized after Charcot's death until the present day [7]. Hystero-epilepsy was made famous in the painting Une Leçons Clinique à la Salpêtrière, by André Brouillet. Charcot was drawn as supporting the lady Blanche on hypnosis [8]. Another monument of hystero-epilepsy is Iconographie Photographique de la Salpêtrière [9]. André Breton and Louis Aragon quoted photographs of a girl, Augustine, with hysteroepilepsy from the photograph series and stated on behalf of surrealism that hysteria was the greatest poetic discovery [10]. With the influences of these great works of art, the current historical view has an archetype image for patients with Charcot's hystero-epilepsy as those seeking fame and has called them 'medical muses' [11] or an 'hysterical circus' [7].

Charcot's pupil Paul Richer sketched many hystero-epilepsy patients with grimaces, oro-lingual-facial movements and arc de cercle, the opisthotonus position in his illustrated book (Fig. 1) [4]. After the discovery of anti-NMDA receptor (NMDAR) encephalitis [12], neurologists identified attacks of oro-lingual-facial dyskinesias and opisthotonic postures similar to those shown in Fig. 1 in anti-NMDAR encephalitis patients. Anti-NMDAR encephalitis is one of the most common types of autoimmune encephalitis that presents as a wide variety of movement disorders [13]. The phenomenological analysis of movement disorders of anti-NMDAR encephalitis patients revealed that the coexistence of chorea, dystonia, and stereotypies affecting the face and the entire body uniquely existed among anti-NMDAR encephalitis and was rare in other neurological conditions [14]. A systematic analysis of the psychopathology of anti-NMDAR encephalitis revealed combinations of various psychotic and mood features that were characteristic among those patients [15]. Typical anti-NMDAR encephalitis progresses through five phases, which last from days to months, namely, the prodromal, psychotic, unresponsive, hypoventilatory and hyperkinetic phases, which are followed by gradual recovery [16]. Charcot introduced five characteristic phases (prodrome, mimicked epilepsy, grand movement, passionate poses, and delirium periods) and abnormal stereotypical movements including arc de cercle as diagnostic signs for hystero-epilepsy $[4,17]$. There is a curious analogy between typical Charcot's hystero-epilepsy and anti-NMDAR encephalitis in their clinical manifestations. 
We previously reported that a small number of patients with symptoms similar to those of anti-NMDAR encephalitis were among the American patients treated with ovariotomy for hysteria and hystero-epilepsy in the nineteenth century [18]. In that paper, we also indicated that the definition of 'hystero-epilepsy' was globally confusing during the late nineteenth century until its disappearance. To elucidate the clinical picture of hystero-epilepsy in the nineteenth century, we analysed the Tuesday Lessons of Charcot.

\section{Methods}

The first edition of the Tuesday Lessons recorded by Charcot's pupils [19], not including the appendix, presented a cumulative total of 190 patients, including 63 patients with hysteria (Table 1). There were slightly more female than male patients. Isolated hysteria tended to be diagnosed more in women, and hysteria with neurosis was diagnosed only in men. Of 63 hysteria patients, 11 were diagnosed with hysteroepilepsy, grand hysteria or grand attack of hysteria due to present or past history by Charcot himself, with detailed descriptions.

Table 1

Hysteria patients in the Tuesday Lessons.

\begin{tabular}{|llll|}
\hline & women (n) & men (n) & sum (n) \\
\hline Total hysteria patients & 35 & 28 & 63 \\
\hline Isolated hysteria without any other complication & 20 & 8 & 28 \\
\hline Post-traumatic hysteria & 7 & 9 & 16 \\
\hline Hysteria as complications of other diseases & 8 & 4 & 12 \\
\hline Hysteria with neurosis & 0 & 7 & 7 \\
\hline Hystero-epilepsy & 7 & 4 & 11 \\
\hline
\end{tabular}

\section{Results}

A summary of the clinical manifestations of the 11 hystero-epilepsy patients is shown in Table 2 . Among them, 7 were women, and 4 were men, with ages ranging from 14 to 53 years. Six patients had isolated hystero-epilepsy, 2 patients had hypnosis-induced hystero-epilepsy, 2 patients were alcohol or morphine abusers with withdrawal syndromes, and the remaining 1 patient had a past history of hystero-epilepsy. Acute onset was stated in 4 patients. Of all the patients, 6 had inducibility or suppressibility by hypnosis or compression of the hysterogenic zone (Patients 2, 5, 6, 8, 9 and 10). Charcot introduced five characteristic phases and abnormal stereotypical movements, especially arc de cercle, as diagnostic for hystero-epilepsy, as well as reactivity to simulation. The diagnosis of hystero-epilepsy was not based on the cause but on clinical manifestations, which involved a combination of hallucinations, neurological deficits, seizures and hyperkinetic signs. 
Table 2

Summary of the hystero-epilepsy patients in the Tuesday Lessons.

\begin{tabular}{|c|c|c|c|c|c|c|c|c|}
\hline $\begin{array}{l}\text { Pt } \\
\text { No. }\end{array}$ & $\begin{array}{l}\text { Lecture } \\
\text { date }\end{array}$ & Patient & Diagnosis & Onset & Symptoms & $\begin{array}{l}\text { Specified } \\
\text { reason for } \\
\text { hystero- } \\
\text { epilepsy } \\
\text { diagnosis }\end{array}$ & $\begin{array}{l}\text { Duration } \\
\text { of each } \\
\text { phase }\end{array}$ & $\begin{array}{l}\text { Specified } \\
\text { negative } \\
\text { hysterical sign }\end{array}$ \\
\hline 1 & $\begin{array}{l}\text { Jan 17, } \\
1888\end{array}$ & $\begin{array}{l}22 \text { y.o. } \\
\text { woman }\end{array}$ & $\begin{array}{l}\text { hysteria, } \\
\text { grand attack }\end{array}$ & $\begin{array}{l}\text { acute onset on Dec. } \\
24 \text { th, } 1887\end{array}$ & $\begin{array}{l}\text { bilateral } \\
\text { incomplete } \\
\text { hands palsy, } \\
\text { hemiaesthesia, } \\
\text { attacks of } \\
\text { movement and } \\
\text { crying, } \\
\text { hallucination of } \\
\text { angry men and } \\
\text { women }\end{array}$ & $\begin{array}{l}\text { existence of } \\
\text { phases }\end{array}$ & $\begin{array}{l}\text { not } \\
\text { mentioned }\end{array}$ & tunnel vision \\
\hline 2 & $\begin{array}{l}\text { Feb 7, } \\
1888\end{array}$ & $\begin{array}{l}\text { juvenile } \\
\text { woman }\end{array}$ & $\begin{array}{l}\text { hystero- } \\
\text { epilepsy }\end{array}$ & 5-6 months before & $\begin{array}{l}\text { contracture, } \\
\text { tonic-clonic } \\
\text { seizure, arc de } \\
\text { cercle } \\
\text { movements, } \\
\text { hallucination }\end{array}$ & $\begin{array}{l}\text { existence of } \\
\text { phases, } \\
\text { inducible by } \\
\text { compression of } \\
\text { the } \\
\text { hysterogenic } \\
\text { zone }\end{array}$ & $\begin{array}{l}\text { varying } \\
\text { within } \\
\text { several } \\
\text { seconds } \\
\text { or minutes } \\
\text { during the } \\
\text { lecture }\end{array}$ & \\
\hline 3 & $\begin{array}{l}\text { Feb 21, } \\
1888\end{array}$ & $\begin{array}{l}14 \text { y.o. } \\
\text { boy }\end{array}$ & $\begin{array}{l}\text { grand } \\
\text { hysteria with } \\
\text { attack of the } \\
\text { third phase }\end{array}$ & $\begin{array}{l}\text { after measles } \\
\text { infection, acute } \\
\text { onset on Jan. 15th, } \\
1888\end{array}$ & $\begin{array}{l}\text { suffocation } \\
\text { attack, arc de } \\
\text { cercle } \\
\text { movement and } \\
\text { hallucination } \\
\text { and memory } \\
\text { deficit }\end{array}$ & $\begin{array}{l}\text { existence of } \\
\text { phases }\end{array}$ & 1 month & $\begin{array}{l}\text { hemiaesthesia, } \\
\text { tunnel vision, } \\
\text { hysterogenic } \\
\text { zone }\end{array}$ \\
\hline 4 & $\begin{array}{l}\text { Mar } \\
27 \\
1888\end{array}$ & $\begin{array}{l}35 \text { y.o. } \\
\text { man }\end{array}$ & $\begin{array}{l}\text { agoraphobia } \\
\text { and past } \\
\text { history of } \\
\text { hystero- } \\
\text { epilepsy } \\
\text { attack } \\
8 \text { years ago }\end{array}$ & acute & $\begin{array}{l}\text { daily seizure } \\
\text { attacks lasting } \\
2-3 \text { hours, a } \\
\text { maximum of } 7 \\
\text { attacks/day }\end{array}$ & $\begin{array}{l}\text { acute onset, } \\
\text { severe } \\
\text { movement } \\
\text { attack, } \\
\text { existence of a } \\
\text { prodrome, and } \\
\text { complete } \\
\text { recovery }\end{array}$ & $\begin{array}{l}\text { not } \\
\text { applicable }\end{array}$ & $\begin{array}{l}\text { phase } \\
\text { progression }\end{array}$ \\
\hline 5 & $\begin{array}{l}\text { May 1, } \\
1888\end{array}$ & woman & $\begin{array}{l}\text { hypnosis- } \\
\text { induced } \\
\text { hystero- } \\
\text { epilepsy, } \\
\text { grand } \\
\text { hypnotism }\end{array}$ & $\begin{array}{l}\text { induction by } \\
\text { hypnosis }\end{array}$ & $\begin{array}{l}\text { somnambulism, } \\
\text { hemiplegia }\end{array}$ & $\begin{array}{l}\text { existence of } \\
\text { phases, } \\
\text { inducible by } \\
\text { hypnosis }\end{array}$ & minutes & \\
\hline 6 & $\begin{array}{l}\text { June } \\
26 \\
1888\end{array}$ & $\begin{array}{l}27 y .0 . \\
\text { woman }\end{array}$ & $\begin{array}{l}\text { hystero- } \\
\text { epilepsy }\end{array}$ & $\begin{array}{l}\text { chronic, first } \\
\text { occurring at } 16- \\
17 \text { years old }\end{array}$ & $\begin{array}{l}\text { epilepsy and } \\
\text { pseudoseizure } \\
\text { attacks, } \\
\text { maximum } 100 \\
\text { attacks/day }\end{array}$ & $\begin{array}{l}\text { suppressibility } \\
\text { by ovarian } \\
\text { compression, } \\
\text { existence of } \\
\text { phases, seizure } \\
\text { attack without } \\
\text { fever }\end{array}$ & $\begin{array}{l}\text { varying } \\
\text { within } \\
\text { several } \\
\text { minutes } \\
\text { during the } \\
\text { lecture }\end{array}$ & \\
\hline 7 & $\begin{array}{l}\text { Nov } \\
13 \\
1888\end{array}$ & $\begin{array}{l}53 \text { y.o. } \\
\text { woman }\end{array}$ & $\begin{array}{l}\text { attacks of } \\
\text { hystero- } \\
\text { epilepsy }\end{array}$ & $\begin{array}{l}\text { chronic, first } \\
\text { occurring at } 18 \text { y.o. }\end{array}$ & $\begin{array}{l}\text { attacks of } \\
\text { stereotypical } \\
\text { abnormal } \\
\text { movements and } \\
\text { hypersomnia }\end{array}$ & $\begin{array}{l}\text { existence of } \\
\text { phases } \\
\text { including } \\
\text { hallucination } \\
\text { and confusion }\end{array}$ & $\begin{array}{l}\text { several } \\
\text { months }\end{array}$ & \\
\hline 8 & $\begin{array}{l}\text { Nov } \\
20 \\
1888\end{array}$ & $\begin{array}{l}27 \text { y.o. } \\
\text { man }\end{array}$ & $\begin{array}{l}\text { infantile } \\
\text { paralysis, } \\
\text { alcoholic } \\
\text { paraplegia, } \\
\text { and hystero- } \\
\text { epilepsy }\end{array}$ & $\begin{array}{l}\text { chronic paraplegia, } \\
\text { subacute attacks of } \\
\text { the others }\end{array}$ & $\begin{array}{l}\text { paraplegia, } \\
\text { amnesia, } \\
\text { conscious } \\
\text { disturbance, } \\
\text { delirium, } \\
\text { epilepsy, arc de } \\
\text { cercle } \\
\text { movement }\end{array}$ & $\begin{array}{l}\text { existence of } \\
\text { phases and } \\
\text { inducible by } \\
\text { compression of } \\
\text { the } \\
\text { hysterogenic } \\
\text { zone }\end{array}$ & $2-3$ hours & \\
\hline
\end{tabular}




\begin{tabular}{|c|c|c|c|c|c|c|c|c|}
\hline $\begin{array}{l}\text { Pt } \\
\text { No. }\end{array}$ & $\begin{array}{l}\text { Lecture } \\
\text { date }\end{array}$ & Patient & Diagnosis & Onset & Symptoms & $\begin{array}{l}\text { Specified } \\
\text { reason for } \\
\text { hystero- } \\
\text { epilepsy } \\
\text { diagnosis }\end{array}$ & $\begin{array}{l}\text { Duration } \\
\text { of each } \\
\text { phase }\end{array}$ & $\begin{array}{l}\text { Specified } \\
\text { negative } \\
\text { hysterical sign }\end{array}$ \\
\hline 9 & $\begin{array}{l}\operatorname{Jan} 29 \\
1889\end{array}$ & $\begin{array}{l}38 \text { y.o. } \\
\text { woman }\end{array}$ & $\begin{array}{l}\text { grand } \\
\text { hysteria } \\
\text { following } \\
\text { hypnosis by } \\
\text { commercial } \\
\text { animal } \\
\text { magnetism }\end{array}$ & $\begin{array}{l}\text { induction by } \\
\text { hypnosis }\end{array}$ & $\begin{array}{l}\text { aphonia, } \\
\text { communicate } \\
\text { only with } \\
\text { writing, tonic } \\
\text { attack }\end{array}$ & $\begin{array}{l}\text { existence of } \\
\text { phases }\end{array}$ & $\begin{array}{l}\text { several } \\
\text { minutes }\end{array}$ & l'arc de cercle \\
\hline 10 & $\begin{array}{l}\text { Feb 5, } \\
1889\end{array}$ & $\begin{array}{l}16 \text { y.o. } \\
\text { girl }\end{array}$ & $\begin{array}{l}\text { hystero- } \\
\text { epileptic } \\
\text { attacks and } \\
\text { hysteric } \\
\text { hypersomnia } \\
\text { following } \\
\text { acute-onset } \\
\text { vomiting } \\
\text { and anorexia }\end{array}$ & $\begin{array}{l}\text { subacute, } 3 \text { months } \\
\text { before the lecture }\end{array}$ & $\begin{array}{l}\text { febrile up to } \\
37.5^{\circ} \mathrm{C}, \\
\text { hypersomnia, } \\
\text { trismus, } \\
\text { repetitive } \\
\text { stereotype } \\
\text { abnormal } \\
\text { movements }\end{array}$ & $\begin{array}{l}\text { existence of } \\
\text { phases } \\
\text { including grand } \\
\text { movement and } \\
\text { passionate } \\
\text { pose phases, } \\
\text { hemiaesthesia, } \\
\text { constriction of } \\
\text { visual fields, } \\
\text { and } \\
\text { hypersensitivity } \\
\text { to ovarian } \\
\text { compression }\end{array}$ & $\begin{array}{l}\text { several } \\
\text { days to } \\
\text { months } \\
\text { long }\end{array}$ & \\
\hline 11 & $\begin{array}{l}\text { Mar } \\
19, \\
1889\end{array}$ & $\begin{array}{l}23 \text { or } \\
24-y .0 . \\
\text { man }\end{array}$ & $\begin{array}{l}\text { epilepsy, } \\
\text { grand } \\
\text { hysteria, } \\
\text { morphine } \\
\text { abuse }\end{array}$ & $\begin{array}{l}\text { after typhoid fever, } \\
\text { hemihyperesthaesia } \\
\text { and pain appeared } \\
\text { and morphine use } \\
\text { began }\end{array}$ & $\begin{array}{l}\text { epilepsy and } \\
\text { hallucinations }\end{array}$ & $\begin{array}{l}\text { existence of } \\
\text { phases }\end{array}$ & $\begin{array}{l}\text { varying } \\
\text { within } \\
\text { several } \\
\text { minutes } \\
\text { during the } \\
\text { lecture }\end{array}$ & \\
\hline
\end{tabular}

Patient 8 was diagnosed with alcoholism and withdrawal, and Patient 11 was diagnosed with chronic pain and morphine withdrawal as well as hystero-epilepsy by Charcot. Patients 2, 5, 6, 7 and 9 had chronic courses. Eventually, 4 patients had an acute-onset combination of multiple neuropsychiatric manifestations without drug use, and 2 patients had phase progression that lasted a month over for grand movement phase, raising the suspicion of the clinical manifestations of anti-NMDAR encephalitis (Table 2, Patients 3 and 10). Patient 3 was a 14-year-old boy who presented with acute-onset apnoea attacks, hallucination, memory deficit, and movement abnormalities, including opisthotonus posturing, over the course of a month following infection as well as problems with school life. Patient 10 was a 16-year-old girl who presented with acute-onset vomiting and anorexia. After recovering her appetite, she developed slight fever and experienced repeated hystero-epileptic attacks including opisthotonus posturing and hypersomnia alternately over 3 months. She had ovarian pain, constriction of visual fields, left-side aesthesia, and could be awakened by an ovarian compression procedure during a hypersomnia phase. There was no evidence that these 2 patients had teratomas.

\section{Discussion}

In the Tuesday Lessons, two hystero-epilepsy patients exhibited clinical resemblance to anti-NMDAR encephalitis. However, due to the lack of evidence of teratomas, we could not reliably retrospectively diagnose these patients with anti-NMDAR encephalitis without cerebrospinal fluid examinations, electroencephalograms, or serological studies, based on the current diagnostic criteria [20]. Moreover, Charcot himself never considered the concept of encephalitis due to ovarian teratoma. He repeatedly opposed the ovarian resections performed as a treatment for hystero-epilepsy conducted in contemporary America [19]. Charcot's hystero-epilepsy has been suspected of being a syndrome encompassing conversion and dissociative disorders, drug withdrawal syndrome, and anti-NMDAR encephalitis-like manifestations.

Opisthotonus posturing and phase progression were used as a basis for the diagnosis of hystero-epilepsy by Charcot's department [1]. Charcot's pupil Richer performed the most important work in the field by recording numerous cases with hystero-epilepsy [4]. In Richer's textbook of hystero-epilepsy, he observed the duration of each phase as lasting from seconds to minutes, which is similar to the duration of epileptic attacks or migraine aura. In contrast, in Charcot's Tuesday Lessons, the durations of the phases varied by as much as months, which was completely different from Richer's records. Even Charcot himself did not declare a common definition for hystero-epilepsy. In the Friday Conference, the formal lectures, Charcot did not mention the phases, stereotypical movements and reactivity to hypnosis and only emphasized that hystero-epilepsy should be distinguished from true epilepsy [21]. 
Soon after Charcot's death, his pupil Joseph Babinski proposed that hysteria was a reproducible psychogenic condition by suggestion [3]. Later neurologists suspected that the disappearance of hystero-epilepsy could be explained by the absence of suggestion after the greatest hypnotist's death or misdiagnosis [11,22]. Charcot's hystero-epilepsy has been largely ignored by later clinicians until today.

During the twentieth century, anti-NMDAR encephalitis had been called acquired reversible autistic syndrome [23], acute encephalopathy of obscure origin [24], and paediatric dyskinetic encephalitis lethargica [25]. Paediatricians recognized a patient group with acute psychosis and executive dysfunction with orofacial dyskinesia, opisthotonic posturing and good prognosis as having acute encephalopathy. Later, one author of the reports wrote that the syndrome was identical to anti-NMDAR encephalitis [26]. Florence and Dalmau listed disorders generally considered in the context of anti-NMDAR encephalitis and previous terms used for disorders likely representing anti-NMDAR encephalitis including acute psychosis, schizophrenia, catatonia, infectious or postinfectious autoimmune encephalitis, drug abuse, acute juvenile female nonherpetic encephalitis and demonic possession [27]. Charcot and Richer wrote Les démoniaques dans l'art, which introduced analogies between medieval demonic possession cases and hystero-epilepsy [17]. We suggest that hystero-epilepsy can be added to the list of the variations in the terms representing anti-NMDAR encephalitis through history.

The similarities between opisthotonus movements in anti-NMDAR encephalitis and the arc de cercle in hystero-epilepsy (Fig. 1) have been indicated previously [28]. However, repetitive opisthotonus movements are not uniquely seen in anti-NMDAR encephalitis. Penfield and Jasper reported alternate repetitions of opisthotonos movements and decerebrate rigidity in a patient with tuberculosis invasion of the midbrain [29]. Repetitive opisthotonus movements with psychiatric changes have been reported in hypoglycaemic psychosis [30], Hashimoto's encephalitis [31], frontal lobe epilepsy [32] and nonepileptic psychogenic seizure [33]. Hystero-epilepsy in the nineteenth century was a clinical phenotype of a heterogenous syndrome and probably included these conditions.

Lethal cases of hystero-epilepsy in the nineteenth century

Although some modern patients, especially paediatric patients, with anti-NMDAR encephalitis have a good prognosis without signs of central hypoventilation, other patients with anti-NMDAR encephalitis have a lethal course with respiratory failure [34]. Some discussion of the condition's mortality would have been necessarily conducted. In fact, Charcot discussed fatal cases of hystero-epilepsy in an annotation of the Tuesday Lesson on 26 June 1888 [19] and in the Friday Conference [21]. Charcot wrote in his book that "this sad result is nearly always owing to a peculiar kind of attack, the dyspnoeic seizure", with temperature elevation, and quoted an autopsy case involving a 19year-old woman reported by Wunderlich. This woman had an acute-onset hysteriform convulsion for several days and was admitted to the hospital, at which point opisthotonus posturing was presented. After eight weeks, the woman exhibited a sudden elevation in temperature and cyanosis and then died. A post-mortem study demonstrated a slight thickening of the pia mater, and her ovaries contained numerous cysts as large as peas. The clinical course of this patient did not conflict with that of anti-NMDAR encephalitis in an era without respiratory assistance or immunomodulating treatments. This case did not present any analogies to nonepileptic psychogenic seizure.

\section{Clinical Relevance}

Charcot's concept of the stigmata of hysteria, such as tunnel vision and centre-dividing aesthesia, still has clinical value for diagnosing functional neurologic disorders including conversion and dissociative disorders [1]. High reactivity to hypnosis is currently one of the diagnostic signs of dissociative disorder. In fact, hypnosis-induced cases among hystero-epileptic patients had no great conflict in recognizing that they had conversion and dissociative disorders including nonepileptic psychogenic seizure $H$ However, modern clinicians have reported cases of anti-NMDAR encephalitis mimicking non-epileptic psychogenic seizures [35] and dissociative disorder [36]. Similarities exist between the clinical presentations of some patients with anti-NMDAR encephalitis and those of conversion and dissociative disorders.

As a result of the prioritization of the characteristic clinical presentation, Charcot also classified the delirium tremens in alcohol and morphine withdrawal syndromes as hystero-epilepsy in the lectures. Modern observations and animal models have shown that chronic alcohol or morphine exposure results in glutamate and NMDAR functional alterations, which are suggested to contribute to the withdrawalrelated central nervous system hyperexcitability [37,38]. Moreover, NMDAR antagonists lead to stereotyped behaviour and psychiatric symptoms that are strikingly similar to those seen in patients with anti-NMDAR encephalitis [27]. The NMDAR antagonist ketamine is a dissociative anaesthetic, characterized by catalepsy, amnesia, and marked analgesia without loss of consciousness or muscle relaxation in patients [39]. Purposeless movements, an increase in muscle tone and resistance to passive motion have been observed since the beginning of ketamine use [39]. These clinical presentations parallel the clinical signs of dissociative coma.

Furthermore, another disease, schizophrenia, has an 'NMDA receptor hypofunction hypothesis' [40]. Schizophrenia overlaps with both dissociative disorder, due to their high co-occurrence [42], and anti-NMDAR encephalitis, with regard to the clinical phenotype [43]. Further interpretation based on Charcot's observations indicates that similar clinical presentations are exhibited among drug withdrawal syndrome,

Page 6/10 
anti-NMDAR encephalitis and conversion and dissociative disorders, leading to the concept of a common molecular dysfunction. To revisit Charcot's challenge of seeking a neuroanatomical basis of hysteria, the function of the glutamate/NMDAR system should be investigated in patients with conversion and dissociative disorders and hypnosis phenomena. It should be determined whether patients with anti-NMDAR encephalitis and drug withdrawal syndrome have dissociative symptoms and high reactivity to hypnosis, especially for the treatment of drug abuse in withdrawal patients.

\section{Conclusion}

Charcot's hystero-epilepsy has been suspected of being a syndrome that includes conversion and dissociative disorders, drug withdrawal syndrome, and anti-NMDAR encephalitis-like manifestations. There are limitations of this study. First, we could not retrospectively diagnose anti-NMDAR encephalitis in Charcot's patients because of the lack of evidence of teratoma. Serological, electrophysiological and imaging studies are necessary to fulfil the present diagnostic criteria to avoid overdiagnosis and the misdiagnosis of other conditions. Presentations with partial resemblances could be found in other neurological diseases, including other encephalitis, hypoglycaemic psychosis, focal epilepsy, and migraine aura. Second, Charcot himself opposed ovarian resections as a treatment for hystero-epilepsy due to ethical concerns regarding opposition to eugenics. Further investigations are required to elucidate Charcot's unaccomplished challenge of characterizing hysteria.

\section{Abbreviations}

NMDAR, $N$-methyl-D-aspartate receptor

\section{Declarations}

\section{Ethics approval and consent to participate}

This study was approved by the Ethics Committee of Dokkyo Medical University (No. 2019-012).

\section{Consent for publication}

The authors reused Paul Richer's sketchs of patients with hystero-epilepsy from the collection of National library of France as Figure 1 according to terms of use for Gallica content.

\section{Availability of data and material}

The datasets analysed during the current study are available in the reference No. 19 (Blin MM, Charcot JB, Colin H. original published 188871889. Policlinique Notes de cours de MM. Blin, Charcot, Henri Colin. Professeur Charcot, Leçons du mardi à la Salpêtrière. Tome I $1887-1888$. Tome II 1888-1889. Reprint. Paris: Claude Tchou pour la Bibliotheque des Introuvables; 2002).

\section{Competing interests}

Komagamine reports receiving manuscript fees from the Asahi Shimbun Company and Shichosha outside the submitted work. Komagamine is a poet and respects André Breton and his mentor Joseph Jules François Félix Babinski. Kokubun reports receiving personal fees from the Japan Blood Products Organization; TEIJIN Pharma Ltd.; Nihon Pharmaceutical Co., Ltd.; and Janssen Pharmaceutical K.K. outside the submitted work. Hirata reports receiving grants and personal fees from Pfizer Japan Inc., Eisai Co., Ltd. and Daiichi Sankyo Company Ltd. as well as grants from A2 Healthcare Corp.; Takeda Pharmaceutical Co., Ltd.; and TAIYO Pharma Co., Ltd. None of these grants pertained to the submitted work.

Hirata reports receiving personal fees from Otsuka Pharmaceutical Co., Ltd.; Mitsui Sumitomo Insurance Co., Ltd.; Boehringer Ingelheim Japan, Inc.; Alfresa Pharma Co., Ltd.; Eisai Co., Ltd.; Novartis Pharma K.K.; Kyowa Hakko Kirin Co., Ltd.; UCB Japan Co., Ltd.; Kowa Company, Ltd.; Mitsubishi Tanabe Pharma Co., Ltd.; Ono Pharmaceutical Co., Ltd.; Nihon Pharmaceutical Co., Ltd.; and MSD K.K. and consulting fees from Pfizer Japan Inc.; Taisho Pharmaceutical Co., Ltd.; Astellas Pharma Inc.; and Boehringer Ingelheim Japan, Inc. outside the submitted work.

\section{Funding}

This research received no specific grant from any funding agency in the public or commercial sector.

\section{Authors' contributions}

Page $7 / 10$ 
The study was designed, analysed and drafted by TK. Critical revision of the manuscript for important intellectual content were made by NK and $\mathrm{KH}$. All of the authors have read and approved the final version of the manuscript.

\section{Acknowledgements}

The authors referenced two books, which is partial translation with commentary of hand-written notes of the Tuesday Lessons (Goetz CG. Charcot, the clinician: the Tuesday lessons. Raven Press Ltd., NY, USA, 1987), and is translation with commentary of second edition of Leçons du mardi à la Salpêtrière (Tsunemaru Sato. Charcot's clinical lessons. Tokyo iji shinshikyoku, TYO, Japan, 1911, which is translated from Sigmund Freud's Übersetzung von J.M. Charcot, Leçons du mardi à la Salpêtrière.) The authors thank to American Journal Experts for the English language review.

\section{References}

1. Goetz CG. Charcot, hysteria, and simulated disorders. Handb Clin Neurol. 2016; 139:11-23.

2. Goetz CG. History of the extensor plantar response: Babinski and Chaddock signs. Semin Neurol. 2002;22:391-398.

3. Guillain G. Transtaled by Bailey P. J.-M. Charcot. His life-his work. London: Pitman Medical Publishing Company; 1959:147-150.

4. Richer P. Études cliniques sur l’hystéro-épilepsie ou grande hystérie 1e ed. Paris: Adrien Delahaye et Émile Lecrosnier. 1881. Source gallica.bnf.fr/National Library of France

5. Bogousslavsky J. Hysteria after Charcot: Back to the Future. Front Neurol 2011;137-161.

6. Aybek A, Vuilleumier P. Imaging studies of functional neurologic disorders. 2016; 139:73-84.

7. Scull A. Hysteria. The disturbing history. New York, NY: Oxford University Press.; 2009:104-130.

8. Goetz CG, Bonduelle M and Gelfand T. Charcot, Constructing Neurology. New York; Oxford University Press, Inc.; 1995 ; $92-93$.

9. Didi-Huberman G. Translated by Hartz A. Invention of hysteria. Charcot and the photographic iconography of the Salpêtrière. Cambridge, Massachusetts, London: The MIT press; 2003.

10. Aragon L, Breton A. Le Cinquantenaire de I'hysterie. Révolution Surréaliste. 1928; 11:20-22. In: La Révolution Surréaliste Collection complete. Paris: Editions Jean Michel Place; 1975.

11. Hustvedt A. Medical muses: Hysteria in nineteenth-century Paris. New York, NY: W. Norton \& Company, Inc.; 2011.

12. Dalmau J, Tüzün E, Wu HY, Masjuan J, Rossi JE, Voloschin A, Baehring JM, Shimazaki H, Koide R, King D, et al. Paraneoplastic anti-N-methyl-D-aspartate (NMDA)-receptor encephalitis associated with ovarian teratoma. Ann Neurol. 2007; 61:25-36.

13. Dalmau J, Lancaster E, Martinez-Hernandez E, Rosenfeld MR, Balice-Gordon R. Clinical experience and laboratory investigations in patients with anti-NMDAR encephalitis. Lancet Neurol. 2011;10: 63-74.

14. Varley JA, Webb AJS, Balint B, Fung VSC, Sethi KD, Tijssen MAJ, Lynch T, Mohammad SS, Britton F, Evans M, et al. The Movement disorder associated with NMDAR antibody-encephalitis is complex and characteristic: an expert video-rating study. J Neurol Neurosurg Psychiatry. 2019;90:724-726.

15. Al-Diwani A, Handel A, Townsend L, Pollak T, Leite MI, Harrison PJ, Lennox BR, Okai D, Manohar SG, Irani SR. The psychopathology of NMDAR-antibody encephalitis in adults: a systematic review and phenotypic analysis of individual patient data. Lancet Psychiatry. 2019;6:235-246.

16. lizuka T, Sakai F, Ide T, Monzen T, Yoshii S, ligaya M, Suzuki K, Lynch DR, Suzuki N, Hata T, Dalmau J. Anti-NMDA receptor encephalitis in Japan: long-term outcome without tumor removal. 2008; 70:504-11.

17. Charcot JM and Richer P. Les démoniaques dans I'art. Original published in 1887. Facsimile reprint; Amsterdam:M. Israël; 1972.

18. Komagamine T, Kokubun N, Hirata K. Battey's operation as a treatment for hysteria: a review of a series of cases in the nineteenth century. Hist Psychiatry. 2019;1-12: DOI:10.1177/0957154X19877145.

19. Blin MM, Charcot JB, Colin H. original published 18887-1889. Policlinique Notes de cours de MM. Blin, Charcot, Henri Colin. Professeur Charcot, Leçons du mardi à la Salpêtrière. Tome I 1887-1888. Tome II 1888-1889. Reprint. Paris: Claude Tchou pour la Bibliotheque des Introuvables; 2002.

20. Graus F, Titulaer MJ, Balu R, Benseler S, Bien SG, Cellucci T, Cortese I, Dale RC, Gelfand JM, Geschwind M, et al. A clinical approach to diagnosis of autoimmune encephalitis. Lancet Neurol. 2016, 15: 391-404.

Page $8 / 10$ 
21. Charcot JM. Translated by Sigerson G. Lectures on the diseases of the nervous system. Delivered at la Salpêtrière. Vol I. Facsimile reprint ed. of the London 1877 New Sydenham Society, Birmingham, Alabama: The classics of Neurology \& Neurosurgery Library, division of Gryphon Editions, Ltd.;1985:300-315.

22. Slater E. Diagnosis of “hysteria”. Br med J. 1965;1:1395-1399.

23. DeLong GR, Bean SC, Brown FR III. Acquired reversible autistic syndrome in acute encephalopathic illness in children. Arch Neurol. 1982;38:191-194.

24. Sébire G, Devictor D, Huault G, Aicardi J, Landrieu P, Tardieu M. Coma associated with intense bursts of abnormal movements and long-lasting cognitive disturbances: an acute encephalopathy of obscure origin. J Pediatr. 1992;121:845-851.

25. Dale RC, Irani SR, Brilot F, Pillai S, Webster R, Gill D, Lang B, Vincet A. N-methyl-D-aspartate (NMDA)-receptor antibodies in paediatric dyskinetic encephalitis lethargica. Ann Neurol. 2009;66:704-709.

26. Sébire G. In search of lost time from “demonic possession” to anti- NMDAR encephalitis. Ann Neurol. 2010;67:141-142.

27. Ryan-Florance N, Dalmau J. Update on anti-N-methyl-D-aspartate receptor encephalitis in children and adolescents. Curr Opin Pediat. 2010;22:739-744.

28. Garcia GD, Nigenda VC, Corona AA, Loza KC, Castillo JC and Rivera JF.Opisthotonus (arc de cercle) in anti-NMDA receptor encephalitis. Arquivos de Neuro-Psiquiatria. 2018. DOI: 10.1590/0004-282X20180047.

29. Penfield W, Jasper H. Epilepsy and the functional anatomy of the human brain. Boston; Little, Brown and Company;1954:382383.

30. Shaw C, Haas L, Miller D, Delahunt J. A case report of paroxysmal dystonic choreoathetosis due to hypoglycaemia induced by an insulinoma. J Neurol Neurosurg Psychiatry. 1996;61:194-195.

31. Mocellin R, Walterfang M, Velakoulis D. Hashimoto's encephalopathy. Epidemiology, pathogenesis and management. CND Drugs. 2007;21:799-811.

32. Williamson PD, Spencer DD, Spencer SS, Novelly RA, Mattson RH. Complex partial seizures of frontal lobe origin. Ann Neurol. 1985;18:497-504.

33. La France, Jr. WC, Ranieri R and Blum AS. Nonepileptic seizures - objective phenomena. Handb Clin Neurol. 2016;139: 297-304.

34. Titulaer MJ, McCracken L, Gabilondo I, Armangué T, Glaser C, lizuka T, Honig LS, Benseler SM, Kawachi I, Martinez-Hermandez E, et al. Treatment and prognostic factors for long-term outcome in patients with anti-NMDA receptor encephalitis: an observational cohort study. Lancet Neurol. 2013;12:157-165.

35. Caplan J, Binius T, Lennon VA, Pittock SJ, Rao MS. Pseudopseudoseizures: conditions that may mimic psychogenic nonepileptic seizures. Psychosomatics. 2011;52: 501-506.

36. Shimoyama Y, Umegaki O, Agui T, Kadano N and Minami T. Anti-NMDA receptor encephalitis presenting as an acute psychotic episode misdiagnosed as dissociative disorder: a case report. JA Clin Rep. 2016;2:22. DOI 10.1186/s40981-016-0048-3.

37. Krystal JH, Petrakis IL, Mason G, Trevisan L and D'Souza DC. N-methyl-D-aspartate glutamate receptors and alcoholism: reward, dependence, treatment, and vulnerability. Pharmacol Ther. 2003;99:79-94.

38. Anderson EM, Reeves T, Kapernaros K, Neubert JK and Caudle RM. Phosphorylation of the $N$-methyl-D -asparate receptor is increased in the nucleus accumbens during both acute and extended morphine withdrawal. Journal of Pharmacol Exp Ther. 2015;355: 496-505.

39. Pender JW. Dissociative anesthesia. JAMA. 1971;215:1126-1130.

40. Coyle JT. NMDA receptor and schizophrenia: a brief history. Schizophr Bull. 2012;38:920-926.

41. Renard SB, Hantjens RJC, Lysaker PH, Moskowitz A, Aleman A, Pijnenborg GHM. Unique overlapping symptoms in schizophrenia spectrum and dissociative disorders in relation to models of psychopathology: a systematic review. Schizophr Bull. 2017;43:108-121.

42. Ando Y, Shimazaki H, Shiota K, Tetsuka S, Nakao K, Shimada T, Kurata K, Kuroda J, Yamashita A, Sato H, et al. Prevalence of elevated serum anti-N-methyl-D-aspartate receptor antibody titers in patients presenting exclusively with psychiatric symptoms: a comparative follow-up study. BMC Psychiatry. 2016;16:226. DOI 10.1186/s12888-016-0948-9.

\section{Figures}



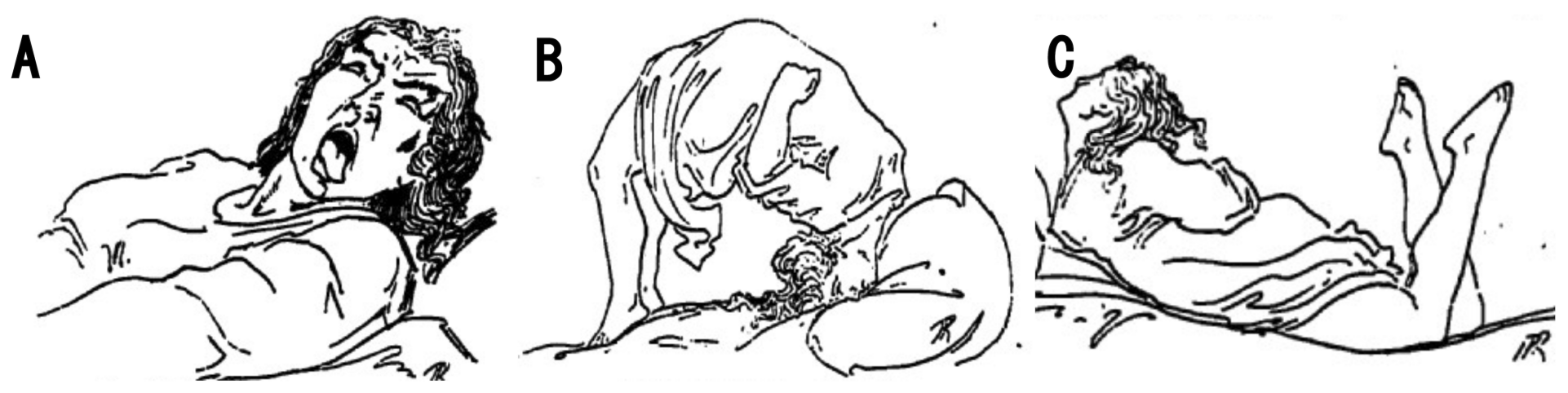

Figure 1

Richer's sketchs of patients with hystero-epilepsy, reproduced with permission from the National library of France. Source gallica.bnf.fr/National Library of France. A: Characteristic presentation of the 'mimicked epilepsy phase' in hystero-epilepsy, which is very similar to orofacial dyskinesia in anti-NMDAR encephalitis patients. B and C: 'L'arc de cercle' posture in the 'grand movement phase' of hystero-epilepsy. The phenomenon was called stigmata in hystero-epilepsy and had such high diagnostic value that displaying this behaviour led to a diagnosis of hysteria without further evaluations in Charcot's department [1]. 